\title{
THE INFLUENCE OF HEAT TREATMENT ON THE MICROSTRUCTURE AND MECHANICAL PROPERTIES OF LAMINATED ALUMINUM BRONZE - INTERMETALLICS COMPOSITES
}

\author{
Marek KONIECZNY, Taras SOROKA \\ Kielce University of Technology, Faculty of Mechatronics and Mechanical Engineering, Department of Metals \\ Science and Materials Technologies, Kielce, Poland, EU, mkon@tu.kielce.pl
}

https://doi.org/10.37904/metal.2019.916

\begin{abstract}
Laminated CuAl10Fe3Mn2-intermetallic phases composites have been produced in vacuum through reactive bonding at $875{ }^{\circ} \mathrm{C}$ using bronze and titanium foils with thickness 0.6 and $0.1 \mathrm{~mm}$, respectively. During fabrication the titanium layers reacted completely and formed $\mathrm{Ti}_{2} \mathrm{Cu}$, TiCuAl and $\mathrm{TiCu}_{2} \mathrm{Al}$ intermetallics. This paper summaries the microstructural changes which take place in laminated composites during heat treatment. Also the mechanical properties and fracture behavior of the heat treated composites were examined through hardness measurements and tensile tests. The results of investigations indicated that tensile properties of the composites strongly depended on the type of applied heat treatment (especially on aging temperature). Upon completing examinations one can define the heat treatment conditions necessary for obtaining optimum properties of laminated CuAl10Fe3Mn2-intermetallic phases composites.
\end{abstract}

Keywords: Laminated composite, aluminum bronze, intermetallics, heat treatment

\section{INTRODUCTION}

Laminated metal-intermetallics composites inosculate the high toughness and ductility of metals with the higher strength, higher elastic modulus, and normally lower density of intermetallics [1-13]. They also have the potential to fulfil various different functions (e.g. ballistic protection, vibration damping, heat exchange, blast mitigation, and thermal management) [5]. Lamination improves fatigue behavior, fracture toughness, corrosion, wear, and damping capacity. It can also ensure enhanced formability for normally brittle intermetallics [6]. Moreover, the laminated structure of the composites permits for variations in the layer thickness and phase volume fractions of the components. A great number of this kind composites have been produced using $\mathrm{Al}$ and $\mathrm{Mg}$ [4], $\mathrm{Nb}$ [6], $\mathrm{Ti}[1,3,5,7,9,10]$, or $\mathrm{Ni}[5,8]$ foils. Previous works also exhibited that copper-intermetallic and titanium-intermetallic composites could be produced by reaction that occurs at the interface of $\mathrm{Ti}$ and $\mathrm{Cu}$ [1113] or $\mathrm{Ti}$ and $\mathrm{Ni}$ [14]. Aluminum bronzes are corrosion-resistant alloys of copper containing from 4 to $15 \mathrm{wt} \%$ aluminum and small amounts of other metals. Alloys containing from 9 to $12 \mathrm{wt} \%$ aluminum are fabricated by sand casting and gravity diecasting into strong objects, including ship propellers and many machine parts or tools [15]. Above $565^{\circ} \mathrm{C}$, the microstructure of alloys with 9.4 to $12 \mathrm{wt} \%$ aluminum consists of two phases with differing proportions of $\alpha$ and $\beta$ grains. At temperatures below $565^{\circ} \mathrm{C}$, the $\beta$ phase decomposes into an eutectoid consisting of $\alpha$ and $\gamma_{2}$ phases, but this pearlite-like structure forms only when the cooling rates are less than $1^{\circ} \mathrm{C} / \mathrm{min}$ [16]. At very high cooling rates these alloys undergo diffusionless transformation, as a result producing the $\beta^{\prime}$ phase, a supersaturated disordered solid solution. It is described as martensite and has face centered cubic structure [17]. Further heat treatment (ageing also called tempering) changes mechanical properties and microstructure of aluminum bronzes [18-20]. The laminated composites with aluminum bronze matrix and intermetallics could be considered for structural applications because of their lower density than monolithic bronze. Designing laminated composites to obtain optimal mechanical requires knowledge of the composite failure mechanism. The aim of this work is to study the influence of heat treatment on the microstructure, mechanical properties and fracture behavior of laminated CuAl10Fe3Mn2 aluminum bronzeintermetallics composites. 


\section{EXPERIMENTAL PROCEDURE}

For bronze-intermetallics laminated composites fabrication six titanium foils $(99.51 \mathrm{Ti}, 0.09 \mathrm{Fe}, 0.08 \mathrm{C}, 0.07$ $\mathrm{Al}, 0.18 \mathrm{O}, 0.05 \mathrm{~V}, 0.02 \mathrm{~N}$ in $\mathrm{wt} \%$ ) of $0.1 \mathrm{~mm}$ thickness were alternatively stacked between seven CuAl10Fe3Mn2 foils (83.36 Cu, 2.78 Fe, $10.75 \mathrm{Al}, 1.98 \mathrm{Mn}, 0.76 \mathrm{Ni}, 0.29 \mathrm{Zn}, 0.08 \mathrm{Sn}$ in wt\%) of $0.6 \mathrm{~mm}$ thickness. Foils were cut into $60 \times 10 \mathrm{~mm}$ rectangular pieces. Any contamination was removed in a bath of $5 \% \mathrm{HF}$ in water. After rinsing in water, foils were stacked into laminates in an alternating sequence. A pressure of $5 \mathrm{MPa}$ was employed at room temperature in a specially constructed vacuum furnace to ensure good contact between foils. Series of attempts allowed to find that a temperature of at least $870^{\circ} \mathrm{C}$ was necessary for the start and rapid development of structural processes at the interface between aluminum bronze and titanium. The temperature was increased from 20 to $800{ }^{\circ} \mathrm{C}$ at a heating rate of $0.25^{\circ} \mathrm{C} / \mathrm{s}$. The samples were heated in vacuum of $0.01 \mathrm{~Pa}$ at $800{ }^{\circ} \mathrm{C}$ for $1 \mathrm{~h}$ under applied $5 \mathrm{MPa}$ pressure to allow diffusion bonding of the layers. After that the foils were heated to $875{ }^{\circ} \mathrm{C}$ and held at this temperature for 60 minutes. The pressure was removed during this processing sequence with the purpose of eliminating possible expulsion of liquid phases. The temperature was then decreased slowly (cooling rate of $0.16{ }^{\circ} \mathrm{C} / \mathrm{s}$ ) to $700{ }^{\circ} \mathrm{C}$ and the pressure of $5 \mathrm{MPa}$ was applied again. Finally, the samples were furnace-cooled to room temperature. After fabrication specimens were heat treated using Czylok chamber furnace without protective atmosphere. The samples for metallographic investigations were cut using diamond blade and polished applying standard techniques. Microstructural observations were performed using a JEOL JMS 5400 scanning electron microscope and a Nikon ECLIPSE MA 200 optical microscope. The chemical composition of the phases was determined by an energy dispersive spectroscopy utilizing a ISIS 300 Oxford Instruments. Before the samples were examined with the optical microscope they had been etched to reveal grain boundaries and the structure of the intermetallic layers. Etching was performed with solution of $40 \mathrm{~g} \mathrm{CrO}_{3}, 7.5 \mathrm{~g} \mathrm{NH}_{4} \mathrm{Cl}$, $8 \mathrm{ml} \mathrm{H}_{2} \mathrm{SO} 4,50 \mathrm{ml} \mathrm{HNO}_{3}$ and $1900 \mathrm{ml} \mathrm{H} \mathrm{H}_{2} \mathrm{O}$. Hardness measurements were performed using a laboratory Vickers hardness tester. Samples with dimensions of $4 \times 8 \times 50 \mathrm{~mm}$ were subjected to tension test on an INSTRON screw machine at a constant crosshead speed of $0.1 \mathrm{~mm} / \mathrm{min}$.

\section{RESULTS AND DISCUSSION}

\subsection{The influence of heat treatment on the microstructure of the laminated composites}

At the beginning of the structural investigations the microstructure of fabricated composites was studied. The microstructure consisted of alternating layers of unreacted bronze and intermetallics (Figure 1).
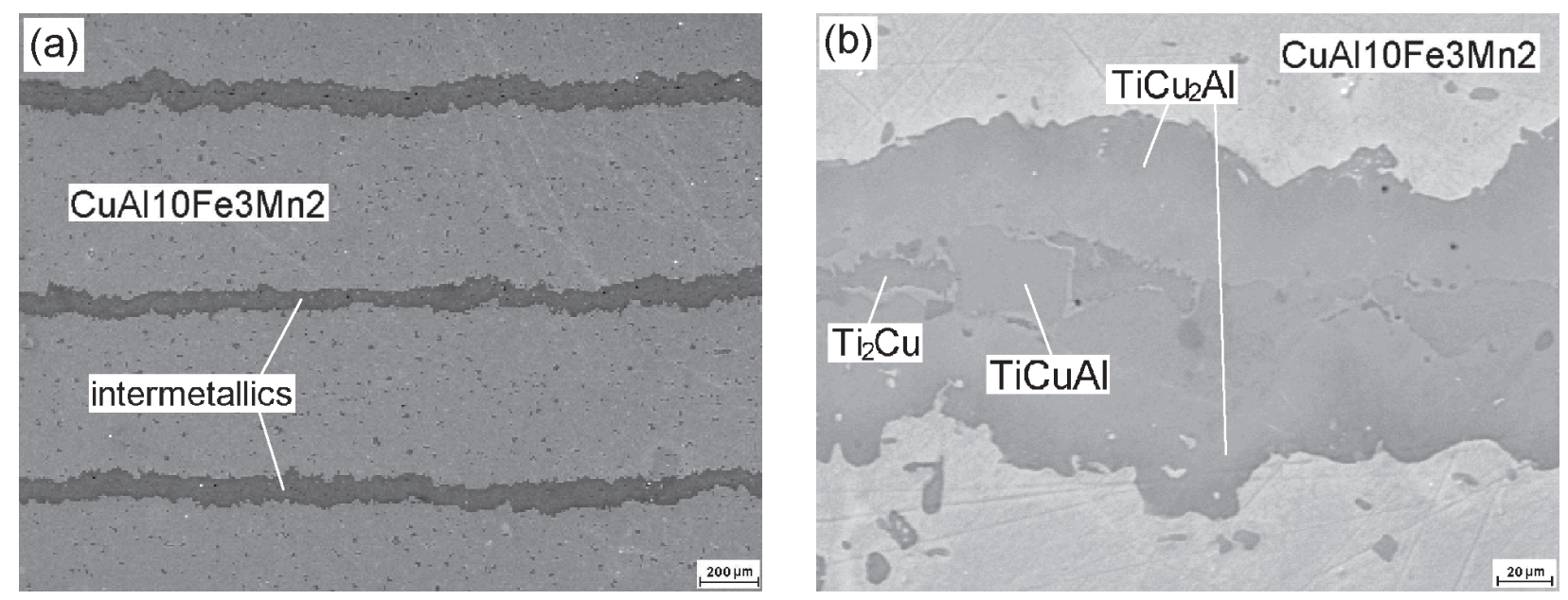

Figure 1 Scanning electron micrographs showing the microstructure of the laminated composite (a) and the composition of the intermetallic layer (b) 
The X-ray analysis shown that intermetallic layers were only composed of three intermetallics: $\mathrm{TiCu}_{2} \mathrm{Al}$ (containing 24.92 at\% Ti, 49.42 at\% Cu, 24.88 at\% Al, 0.41 at\% $\mathrm{Fe}$ and 0.37 at\% Mn), TiCuAl (containing $32.85 \mathrm{at} \% \mathrm{Ti}, 36.74 \mathrm{at} \% \mathrm{Cu}, 30.04$ at\% $\mathrm{Al}, 0.23$ at\% $\mathrm{Fe}$ and 0.14 at\% $\mathrm{Mn}$ ) and $\mathrm{Ti} 2 \mathrm{Cu}$ (containing 61.91 at\% $\mathrm{Ti}$, $31.01 \mathrm{at} \% \mathrm{Cu}, 6.17 \mathrm{at} \% \mathrm{Al}, 0.33$ at\% $\mathrm{Fe}$ and 0.58 at\% $\mathrm{Mn}$ ) that could dissolve up to 8 at\% $\mathrm{Al}$ [17]. The predominant part of the intermetallic layers were $\mathrm{TiCu}_{2} \mathrm{Al}$ and $\mathrm{TiCuAl}$ phases, since a liquid front of reaction was moving into the aluminum bronze. The heat treatment experiments were designed to encompass a range of heat treatment schedules for the laminated composites, and they were based on temperatures recommended in the CuAl10Fe3Mn2 data sheet. The specimens were heated in a laboratory electrical furnace without any protective atmosphere. The specimens were placed in the furnace at room temperature, and heating to $850^{\circ} \mathrm{C}$ took place in 60 minutes. Next the specimens were cooled rapidly in water. The resulting microstructure of laminated composites consisted of alternating layers of martensite and intermetallics (Figure 2).

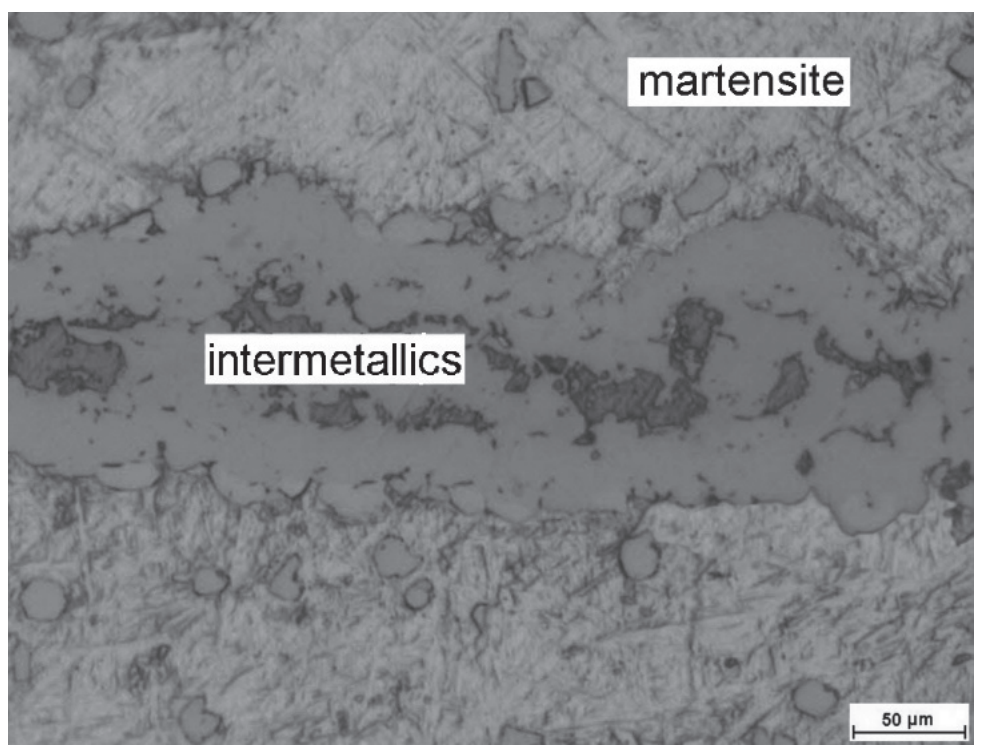

Figure 2 Microstructure of sample heated for 60 minutes at $850^{\circ} \mathrm{C}$ and cooled in water

Subsequent aging at 350 and $550{ }^{\circ} \mathrm{C}$ changed the microstructure of the layers of aluminum bronze in composites but microstructure of intermetallics was still the same (Figure 3 ).
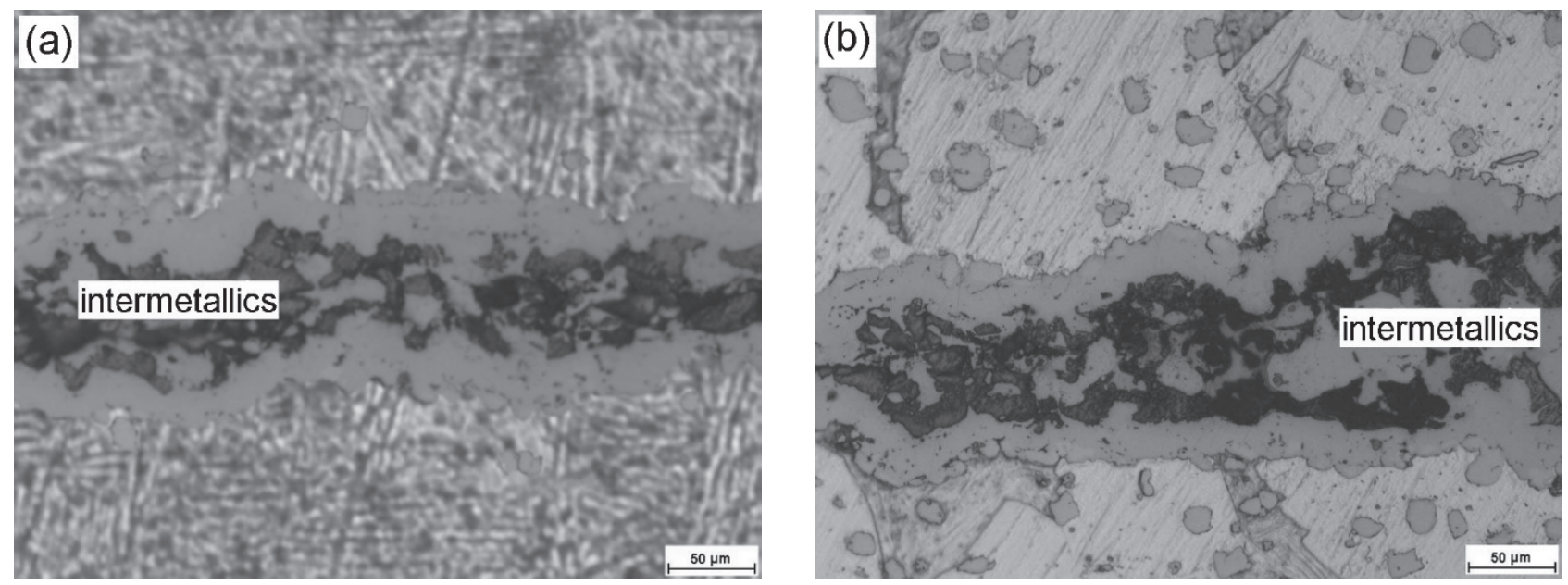

Figure 3 Microstructure of hardened and after that aged specimens at 350 (a) and $550{ }^{\circ} \mathrm{C}(\mathrm{b})$ 


\subsection{The influence of heat treatment on the hardness of the laminated composites}

Hardness measurements were performed for composites before and after heat treatment. Results are given in Table 1.

Table 1 Results of hardness measurements (HV30)

\begin{tabular}{|c|c|c|c|c|}
\hline $\begin{array}{c}\text { As-processed } \\
\text { laminated } \\
\text { composite }\end{array}$ & $\begin{array}{c}\text { Hardened laminated } \\
\text { composite }\end{array}$ & $\begin{array}{c}\text { Laminated } \\
\text { composite hardened } \\
\text { and aged at } 350^{\circ} \mathrm{C}\end{array}$ & $\begin{array}{c}\text { Laminated } \\
\text { composite hardened } \\
\text { and aged at } 550^{\circ} \mathrm{C}\end{array}$ & Intermetallic layer \\
\hline 276 & 485 & 441 & 383 & 585 \\
\hline
\end{tabular}

The maximum hardness values were achieved for intermetallic layers due to the presence of the $\mathrm{TiCu}_{2} \mathrm{Al}$ intermetallic phase. The hardness of the base bronze was $276 \mathrm{HV} 30$. Hardening increased this value to 485 , and after ageing hardness decreased to 441 and $383 \mathrm{HV} 30$ at temperatures of 350 and $550{ }^{\circ} \mathrm{C}$, respectively. It is worth to note that the hardness of intermetallic layers did not change after ageing at any of the used temperatures and was 585 HV30.

\subsection{The influence of heat treatment on the tensile properties and fracture behavior}

Figure 4 shows the typical tensile stress-strain curves for the processed laminated composite and composites after heat treatment.

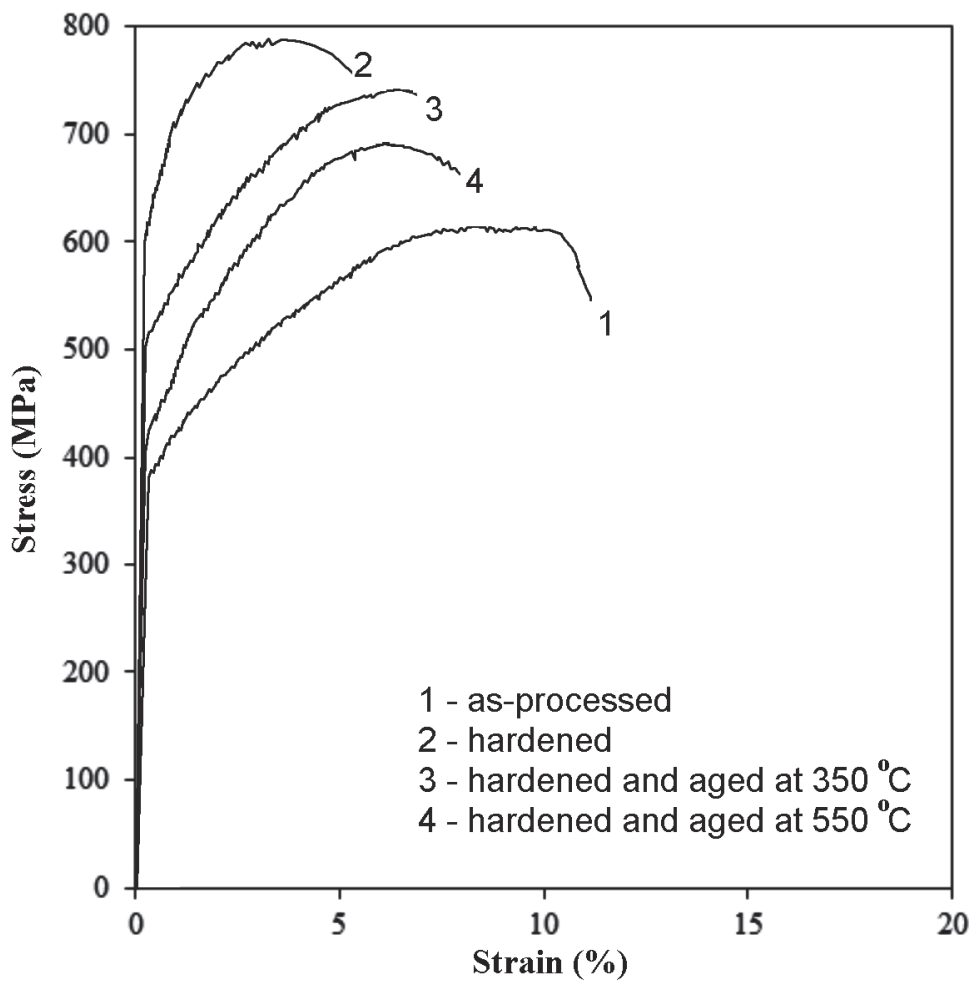

Figure 4 Tensile curves for the laminated CuAl10Fe3Mn2-intermetallics composites

The adopted heat treatment changes tensile properties of the laminated composites in a wide range. Hardening leads to an increase in the yield (YS) and tensile strength (UTS) and decrease in the total strain at fracture. Subsequent ageing leads to decrease in the yield and tensile strength but the strain at fracture 
increases proportionally to the increase of heat treating temperature. Table 2 summarizes the tensile properties of synthesized composites.

Table 2 Summary of tensile properties of CuAl10Fe3Mn2-intermetallics laminated composites

\begin{tabular}{|c|c|c|c|c|}
\hline Tensile properties & $\begin{array}{c}\text { As-processed } \\
\text { laminated } \\
\text { composite }\end{array}$ & $\begin{array}{c}\text { Hardened laminated } \\
\text { composite }\end{array}$ & $\begin{array}{c}\text { Laminated } \\
\text { composite hardened } \\
\text { and aged at } \mathbf{3 5 0} \mathbf{~}^{\circ} \mathbf{C}\end{array}$ & $\begin{array}{c}\text { Laminated } \\
\text { composite hardened } \\
\text { and aged at } \mathbf{5 5 0}{ }^{\circ} \mathbf{C}\end{array}$ \\
\hline YS (MPa) & 380 & 605 & 510 & 420 \\
\hline UTS (MPa) & 610 & 780 & 735 & 690 \\
\hline Elongation (\%) & 12 & 6 & 7 & 8 \\
\hline
\end{tabular}

The failure mechanism in the course of straining of the composites was carefully investigated. At the early stage of plastic straining the aluminum bronze grains were deformed by slip. The phenomenon was observed for all composites, both, as-processed and heat treated. No traces of plastic deformation were noticed in the intermetallic layers. Unfortunately, during deformation the crystal structures mismatch between phases makes almost impossible slip-bands slide through an alloy/intermetallic interfaces. Therefore, formation of cracks in the intermetallic layers was the characteristic feature of the prolonged deformation. The serrations in the stress-strain curves in Figure 4 correspond to the formation of the multiple cracks in the intermetallic layers. The energy absorption capability of the aluminum bronze layers allowed numerous cracks to develop within each intermetallic layer before failure. With permanent increase of the crack number in the intermetallic layers the bronze layers gradually underwent the total external load. As a result the plastic flow that took place in the alloy layers was restricted to the small regions between opposite cracks in the neighboring intermetallic layers. When the number and distribution of cracks reached a critical limit, the final failure occurred by shearing fracture of the aluminum bronze layers. It is obvious that strain hardening of the tensile specimens was produced due to plastic deformation of the aluminum bronze layers. For hardened composites the strain hardening was the fastest. Ageing temperature slowed down the process. The obtained data are consistent with the results reported by Thiyaneshwaran et al. [2] and Zhou et al. [3]. The failure characteristic described for the aluminum bronze-intermetallic phases composites is strictly consistent with previous studies of cracking and damage mechanisms in various laminated composites $[2,3,5-9,12]$. The damage mechanisms of the unlike laminated composites during tensile testing are alike because different intermetallics formed from different constituent metals behave very similar. They normally are brittle due to the limited mobility of dislocations, and have very low surface energy resulting in little or no plastic deformation at crack tips.

\section{CONCLUSION}

The results of investigations indicated that microstructure and tensile properties of the laminated composites strongly depended on the type of applied heat treatment. The resulting microstructure of laminated composites after hardening consisted of alternating layers of martensite and intermetallics. Subsequent aging at 350 or $550{ }^{\circ} \mathrm{C}$ changed the microstructure of the layers of aluminum bronze in composites but microstructure of intermetallics was still the same. The results of hardness measurements indicated that hardness of the base bronze was $276 \mathrm{HV} 30$ and hardening increased this value to $485 \mathrm{HV} 30$. Subsequent ageing at 350 and $550{ }^{\circ} \mathrm{C}$ decreased hardness to 441 and $383 \mathrm{HV} 30$, respectively. The yield and tensile strength of all heat treated composites were higher than for as-processed laminated composites, and for hardened materials were higher even 59 and $28 \%$, respectively. Strain hardening of the tensile specimens was produced due to plastic deformation of the aluminum bronze layers. For hardened composites the strain hardening was the fastest. Ageing temperature slowed down the process. 


\section{REFERENCES}

[1] LAZURENKO, D.V., BATAEV, A., MALI, V.I., JORGE, A.M., STARK, A., PYCZAK, F., OGNAEVA, T.S. and MALIUTINA, I.N. Synthesis of metal-intermetallic laminate (MIL) composites with modified $\mathrm{Al}_{3} \mathrm{Ti}_{\mathrm{i}}$ structure and in situ synchrotron X-ray diffraction analysis of sintering process. Materials \& Design. 2018. vol. 151, pp. 8-16.

[2] THIYANESHWARAN, N., SIVAPRASAD, K. and RAVISANKAR, B. Work hardening behavior of Ti/Al-based metal intermetallic laminates. International Journal of Advanced Manufacturing Technology. 2017. vol. 93, pp. 361-374.

[3] ZHOU, P., GUO, C., WANG, E., WANG, Z., CHEN, Y. and JIANG, F. Interface tensile and fracture behaviour of the $\mathrm{Ti} / \mathrm{Al}_{3} \mathrm{Ti}$ metal-intermetallic laminate (MIL) composite under quasi-static and high strain rates. Materials Science and Engineering A. 2016. vol. 665, pp. 66-75.

[4] DZIADOŃ, A., MOLA, R. and BŁAŻ, L. Formation of layered Mg/eutectic composite using diffusional processes at the Mg-Al interface. Archives of Metallurgy and Materials. 2011. vol. 56, pp. 677-684.

[5] ALMAN, D., DOGAN, C.P., HAWK, J.A., RAWERS, J.C. Processing, structure and properties of metalintermetallic layered composites. Materials Science and Engineering A. 1995. vol. 192-193, pp. 624-632.

[6] BLOYER, D.R., VENKATESWARA RAO, K.T., RITCHIE, R.O. Laminated Nb/Nb 3 Al composites: effect of layer thickness on fatigue and fracture behaviour. Materials Science and Engineering A. 1997. vol. 239-240, pp. 393398.

[7] VECCHIO, K.S. Synthetic multifunctional metallic-intermetallic laminated composites. JOM. 2005. vol. 57, pp. 2531.

[8] WANG, H., HAN, J., DU, S., NORTHWOOD, D.O. Effects of Ni foil thickness on the microstructure and tensile properties of reaction synthesized multilayer composites. Materials Science and Engineering A. 2007. vol. 445446, pp. 517-525.

[9] PENG, L.M., LI, H., WANG, J.H. Processing and mechanical behavior of laminated titanium-titanium tri-aluminide (Ti-Al $\mathrm{T}_{3} \mathrm{Ti}$ ) composites. Materials Science and Engineering A. 2005. vol. 406, pp. 309-318.

[10] HARACH, D.J., VECCHIO, K.S. Microstructure evolution in metal-intermetallic laminate (MIL) composites synthesized by reactive foil sintering in air. Metallurgical and Materials Transactions A. 2001. vol. 32, pp. 14931505.

[11] DZIADOŃ, A., KONIECZNY, M. Structural transformations at the Cu-Ti interface during synthesis of copperintermetallics layered composite. Kovové Materiály-Metallic Materials. 2004. vol. 42, pp. 42-50.

[12] KONIECZNY, M., DZIADOŃ, A. Mechanical behavior of multilayer metal-intermetallic laminate composite synthesized by reactive sintering of $\mathrm{Cu} / \mathrm{Ti}$ foils. Archives of Metallurgy and Materials. 2007. vol. 52, pp. 555-562.

[13] KONIECZNY, M. Deformation mechanisms in copper-intermetallic layered composite at elevated temperature. Kovové Materiály-Metallic Materials. 2007. vol. 45, pp. 313-317.

[14] SZWED, B., KONIECZNY M. Microstructure and mechanical properties of joints of titanium with stainless steel performed using nickel filler. Archives of Metallurgy and Materials. 2016. vol. 61, no. 2B, 997-1001.

[15] GAZDA, A., GÓRNY, Z., KLUSKA-NAWARECKA, S., SAJA, K., WARMUZEK, M. Effect of modification and heat treatment (solution heat treatment and solution heat treatment + ageing) on structure and mechanical properties of CuAl10Fe3Mn2 bronze. Works of Foundry Research Institute. 2010. vol. 12, pp. 37-63.

[16] HAJEK, J., KRIZ, A., CHOCHOLATY, O., PAKUŁA, D. Effect of heat treatment on microstructural changes in aluminum bronze. Archives of Metallurgy and Materials. 2016. vol. 41, no. 3, pp. 1271-1276.

[17] BREZINA, P. Heat treatment of complex aluminum bronzes. International Metals Reviews. 1982. vol. 27, no. 2, pp. 77-120.

[18] KAPLAN, M., YILDIZ, A.K. The effects of production methods on the microstructures and mechanical properties of aluminum bronze. Materials Letters. 2003. vol. 57, pp. 4402-4411.

[19] HUSSEIN, A.A. Structure-property relationship in dual-phase Cu-Al alloys: part I. Individual phases. Metallurgical Transactions A. 1982. vol. 13, pp. 837-846.

[20] JAIN, P., KUMAR NINGAM, P. Influence of heat treatment on microstructure and hardness of nickel aluminum bronze (Cu-10Al-5Ni-5Fe). Journal of Mechanical and Civil Engineering. 2013. vol. 4, no. 6, pp. 16-21. 